\title{
KiSS-1 Receptor
}

National Cancer Institute

\section{Source}

National Cancer Institute. KiSS-1 Receptor. NCI Thesaurus. Code C29643.

KiSS-1 receptor (398 aa, $43 \mathrm{kDa}$ ) is encoded by the human KISS1R gene. This protein plays a role in the onset of puberty and the suppression of tumor metastasis. 